\title{
Sandalwood plantations - points to ponder
}

\author{
Doddabasawa $^{1, *}$ and B. M. Chittapur ${ }^{2}$ \\ ${ }^{1}$ Division of Farm Forestry, College of Agriculture, Bheemarayanagudi, Yadgir 585 287, India \\ ${ }^{2}$ Directorate of Extension, University of Agricultural Sciences, Raichur 584 104, India
}

East Indian sandalwood (Santalum album L.) is one of the precious woods known for sweet fragrant aroma and commercial value in both national and international markets. Besides, its wide adaptability to varied climate, hosts and edaphic conditions have attracted farmers and corporates for commercial venture. Sandalwood being a hemi-root parasite, the successful establishment of sandalwood plantation depends on the understanding of parasitism ecology, especially the relations between host and parasite, their ratio and other silviculture techniques. Hence, the present article aims to understand these issues for commercial upscaling. Sandalwood relies largely on host plants for mineral nutrients and water through haustorial connections which act as a physiological and physical bridge between the parasite and the host. It parasitizes over a vast array of plants from grasses to trees, whereas leguminous associations are superior. Deeprooted and slow-growing perennial hosts help in sustained growth. For better yield of heartwood and oil sandalwood should be grown over 15 years, whereas optimum rotation age would be $25-30$ years. Sandalwood can be planted either through direct dibbling of seeds near the hosts in the same pit or adjacent to the hosts. Better establishment occurs when sandalwood is grown with potted host followed by secondary hosts in the field. Association of sandalwood and host would be strong when the distance is around $2.5-3 \mathrm{~m}$ with host to parasitic ratio of $2: 1$ or $3: 1$. However, questions on parasitism ecology still remain.

Keywords: Ecology, haustoria, hosts, parasite, sandalwood.

IN recent times farmers are showing great interest in growing a few economically important tree species in the form of plantations and as integral component of agroforestry systems. Sandalwood is one such species which is gaining wider attention among farming and corporate communities for its high economic value. India is the major exporter of East Indian sandalwood in the world, accounting for $90 \%$ of the total global production. Most of the produce comes mainly from natural stands, wherein presently sandalwood trees are under tremendous pressure due to indiscriminate exploitation, especially for high export value of wood ${ }^{1}$ coupled with poor regeneration, fire, disease and change in land-use pattern ${ }^{2-4}$.

\footnotetext{
*For correspondence. (e-mail: dkpati12020@gmail.com)
}

Consequently, the production has reduced from 400 to $500 \mathrm{Mg}$ (mega gram) year ${ }^{-1}$, whereas the global demand is between 5000 and $6000 \mathrm{Mg}$ year $^{-1}$ (ref. 5). The declining natural stock has increased the price of sandalwood in the national and international market by many folds ${ }^{2,6,7}$, and East Indian sandalwood continues to enjoy the prime position attracting greater commercial venture ${ }^{8}$.

However, regeneration and establishment of sandalwood plantations were mostly unsuccessful because of poor understanding of parasitism ecology, i.e. sandalwoodhost relationship 9 . Being a hemi-root parasite, it has unique and complex silvicultural characteristics ${ }^{10}$. Further, lack of precise information on cultivation practices is a hindrance in the successful establishment of sandalwood. Here we review the available information to suggest the best possible establishment techniques.

\section{About sandalwood}

Genus Santalum belongs to the family Santalaceae consisting of 16 species and their variants most of which are geographically and reproductively isolated ${ }^{11,12}$. These are known for their fragrant heartwood and oil. Most sandal species are small trees or large shrubs with erect or dropping branches. All the sandal species are slow-growing and root parasites. A few sandal species are commercially important in terms of quality and quantity of aromatic oil. Among these, Santalum album L. considered the queen of sandal species having higher concentration (6-7\%) and good quality oil with sweet, fragrant and persistent aroma is used in perfumes, cosmetics and medicine ${ }^{1,13}$. Further, the soft wood is also used in carvings and intricate designs. The natural distribution of sandalwood extends from $30^{\circ} \mathrm{N}$ to $40^{\circ} \mathrm{S}$, that is, from Indonesia in the east to Juan Fernandez Islands (Chile) in the west and from Hawaiian Archipelago in the north to New Zealand in the south. Wide distribution occurs in India with highly concentrated population in the peninsular region, mainly in Karnataka, Tamil Nadu and Kerala ${ }^{11,14}$.

It is a small to medium-sized evergreen tree species that prefers shade in the early stages, while in the later stages the plant requires abundant sunlight for luxuriant growth. Initial growth is slow and the plant attains a height of 12-15 m and girth of 1-2.4 m (ref. 15). Sandal grows well under varied climatic conditions up to an altitude $1800 \mathrm{~m}$, prefers warm to monsoon climate (500$3000 \mathrm{~mm}$ rainfall), and flourishes well under dry 
monsoon climate receiving $600-1600 \mathrm{~mm}$ rainfall. It adapts as well to cool climate and long dry periods and grows well on a wide variety of soils comprising sandy, clay, red and lateritic loamy and even black cotton soils. However, well-drained light to medium soils are preferred. Whereas, it does not tolerate waterlogged soils and cool climatic conditions ${ }^{16,17}$. Its wide adaptability, nonspecific parasitization (parasitizes more than 300 plant species), and high economic value are attracting the farming community for commercial production.

\section{Parasitism}

Sandalwood is a hemi-root parasitic tree and relies largely on host plants for mineral nutrients and water. The hemi-parasitic nature was first detected by Scott in 1981 and later confirmed by Barber ${ }^{18,19}$, who studied the root system of sandalwood in detail and reported haustorial formation on the rootlets. The formation of haustoria is more or less confined to younger roots; the main roots probably play little part in the absorption of nutrients (Figure 1). In the absence of a host, the haustorium remains small and ultimately withers away, but if a rootlet of a suitable host is present, it grows rapidly assuming the shape of a flattened bell. Sandal root and the host develop direct vascular connections, which later undergo secondary growth ${ }^{20,21}$. The vascular connection between the host and sandal becomes so intimate that the host root and parasite root become almost a single physiological unit, a physical and physiological bridge (Figure 2 ) $^{22}$. Further, hosts are not only important for fulfilment of nutrient and water needs, but also provide shade in the early stages of sandal growth when necessary ${ }^{23,24}$. Some reports suggest the dependence of sandal on hosts for $\mathrm{Ca}, \mathrm{Fe}$ (ref. 25), N, P (ref. 26), K, and Mg (refs 27, 28), whereas others include amino acids, proline, malic acid and sugars for the synthesis of carbohydrates ${ }^{13,29}$.

Sandal requires a host for survival from seedling to maturity ${ }^{13,30-32}$, though in the early stages it derives its nutritional requirements from the seed reserve and soil ${ }^{33}$. It can survive up to 1 year without a host. Nagaveni and Srimathi ${ }^{34,35}$ observed poor survival of sandal without host after the second and third years, necessitating the presence of host plants in later stages ${ }^{36}$. Ehrhart and Fox ${ }^{31}$ identified host requirement at three different stages for successful establishment, one at the seedling stage (the primary host/pot host) involving planting of host plants in containers having sandalwood seedlings during nursery propagation; second at intermediate between nursery and field, and third stage as long-term host in the field throughout the life of the sandal tree (secondary host). However, in practice hosts are being largely used at two stages, viz. as primary hosts in seedling stage for a short period ( 6 months to 2 years) and secondary hosts in the field as long-term hosts. The parasitic nature of sandal and beneficial influence of host plants on the growth of sandal are widely studied ${ }^{13,30,37-39}$. However, what exactly sandal draws from its hosts is still unclear.

\section{Host}

Host selection is an important factor for the successful establishment of sandal plantations ${ }^{13}$. Sandal is known to parasitize a large number of plants from grasses to trees. In some instances, it was found to resort to self-parasitism ${ }^{40}$.

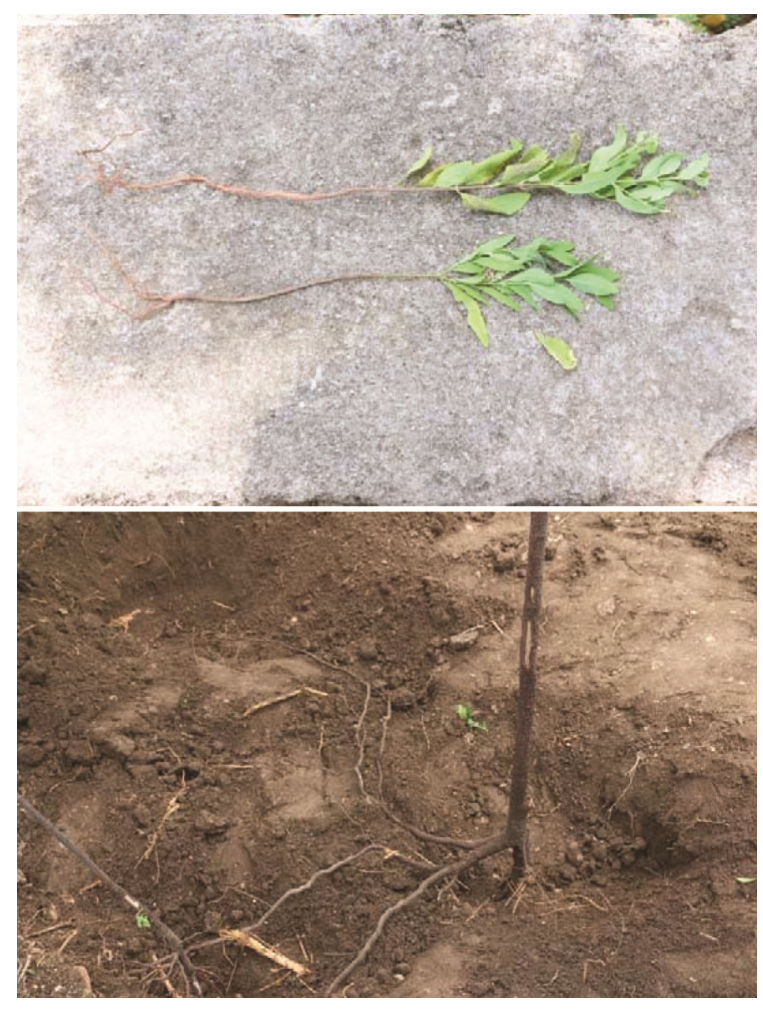

Figure 1. Rooting pattern of sandalwood.

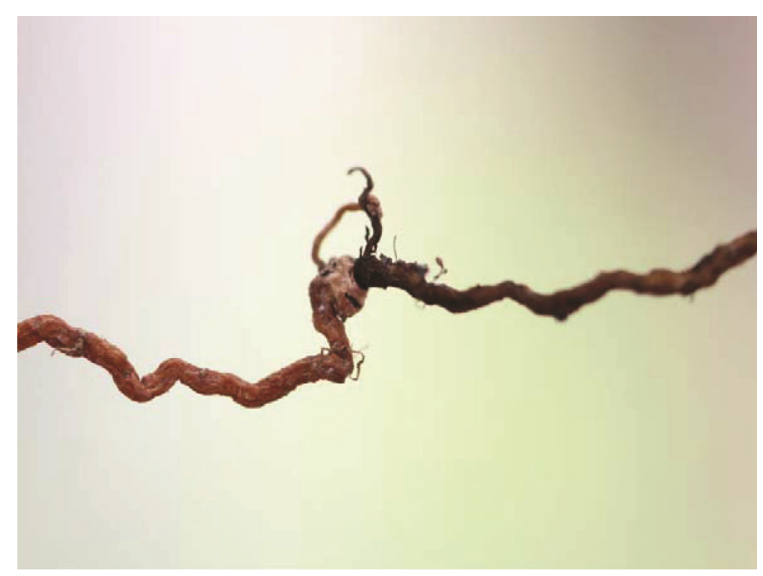

Figure 2. Physiological and physical bridge between sandalwood and host through haustorial connection (left-hand side sandalwood root and right-hand side host root). 
Further, differential growth responses of sandal were observed with different hosts ${ }^{41}$. Pot-culture studies helped identify good, moderately good and poor host species based on the number of haustoria produced, and interaction of parasitism on growth and performance of sandal and its host on the basis of survival, growth, vigour and mortality rate of both sandal and host ${ }^{42-45}$. Usually with suitable hosts the sandal trees have thick canopy, wider and darker green leaves, in contrast to small and yellow chlorotic leaves with unsuitable hosts ${ }^{46}$.

The size and shape of the haustorial formation depend on the type of host attachment ${ }^{47}$. Better growth of sandalwood was observed with leguminous host species such as Acacia, Sesbania, etc. ${ }^{30,48}$ (Table 1), probably due to higher availability of nitrogen which might increase the number and size of haustorial formation ${ }^{30,49}$. Leguminous species also have thin roots with watery skin root which helps in easy penetration and formation of haustorial connection. Acacia was the most preferred host under natural condition ${ }^{30,50,51}$. However, it is better to have multiple compatible hosts consisting of both leguminous and non-leguminous species. Multiple hosts are expected to reduce the parasitic load, as in most instances the establishment of sandal plantations with one or two individuals of the same host species has resulted in the decline or death of hosts as well as sandalwood after 5-10 years due to parasitic load ${ }^{52}$. Inclusion of multiple species ensures long-term survival of sandal and hosts. Further, presence of multispecies increases the seasonal source of water and nutrients ${ }^{10}$. Barrett et al. ${ }^{53}$ attributed variations in the distribution of nutrient within the shoots and leaves of Santalum spicatum to contribution from diverse host species. The differential requirement of water and nutrients by different host species could be another reason for the potential survival of sandalwood.

\section{Preferred perennials}

The formation of heartwood is influenced by the host on which sandal is parasitized, the edaphic and climatic factors as well as age. Basically, sandal is a slow-growing species, displaying an increment of $1 \mathrm{~cm}$ girth year ${ }^{-1}$ under natural conditions, however, under favourable conditions, increment in girth extends to $5-6 \mathrm{~cm}_{\text {year }}{ }^{-1}$ (refs $17,54)$. Normally, heartwood initiation begins around $10-13$ years in India ${ }^{40}$, whereas economical rotation age is between 30 and 60 years $^{55}$. Further, the concentration and composition of oil also varies with maturity. For instance, young trees of 10 years having $>16 \mathrm{~cm}$ diametre are found to have $0.2-2.5 \%$ of oil and $60-85 \%$ santalols, whereas mature trees that are 30-50 years old with $<32 \mathrm{~cm}$ diameter have $2.8-5.6 \%$ oil and $90 \%$ santalols $^{56}$. Therefore, the most economical rotation age of sandal would be around 30 years or more, to obtain higher quantity and quality of heartwood and oil ${ }^{55}$. There are instances where it is advised to harvest at the age of 15 years for financial reasons ${ }^{57,58}$. However, there is little published information on the productivity of heartwood at this age ${ }^{59}$. Jonathan et al. ${ }^{59}$ reported average heartwood and oil concentration per tree of 5.8 and $0.28 \mathrm{~kg}$ respectively, 16-year-old Indian sandalwood planted with a density of 260 trees ha ${ }^{-1}$ in Kununurra, Western Australia, which was half the expected yield at this age. Therefore, they suggested enhancing the rotation period for maximization of yield. A few other studies also suggested a rotation period exceeding 15 years ${ }^{13}$.

The appropriate economical rotation age of sandalwood would be between 25 and 30 years with perennial host species having rotation period of over 30 years. Some studies have also indicated a few short- and medium-rotation tree species such as Casuarina equisetifolia, Acacia mangium, etc. to be good hosts for sandal but harvested between 8 and 12 years and, therefore, should not be selected as long-term hosts. In general, perennial species are to be preferred over annuals and/or short rotation species to sustain sandal for longer periods ${ }^{60-63}$.

\section{Rooting pattern in hosts}

It is evident that sandalwood depends on hosts for mineral nutrients and water ${ }^{64-67}$. Rocha et al. ${ }^{68}$ observed higher pre-dawn water potential $(-0.85 \mathrm{MPa})$ in sandalwood with host than without host $(-1.27 \mathrm{MPa})$. They observed reduction in water potential after removal of host which resulted in wilting and leaf-shedding of sandal, thus affecting growth and productivity. Therefore, host plants are necessary to maintain better water potential in sandalwood. Shallow-rooted annuals and perennial hosts may not be good as they are unable to supply water to support sandal during the dry period. Preference, therefore, should be given to deep-rooted hosts which access water from deeper layers during drought ${ }^{69}$.

\section{Preferred economic hosts}

Long gestation period of sandalwood has resulted in the inclusion of some economically important horticultural species which help get interim returns ${ }^{70,71}$. Viswanath et $a .^{72}$ observed better growth of sandal with mango (Mangifera indica) under intensively managed plantations, followed by amla (Phyllanthus emblica). Singh et $a l{ }^{73}$ found greater height, collar diameter, crown size, clear bole and survival of sandal with Citrus aurantium compared to Casuarina equisetifolia and Punicum grantum. Nevertheless, too little information is available to draw any generalization on suitability of species for a particular agro-climatic region. However, inclusion of suitable multiple host species of commercial importance comprising $\mathrm{N}_{2}$-fixing and non-fixing tree species needs consideration for a viable system. Parasitism can suppress the biomass and photosynthesis of the associated host 


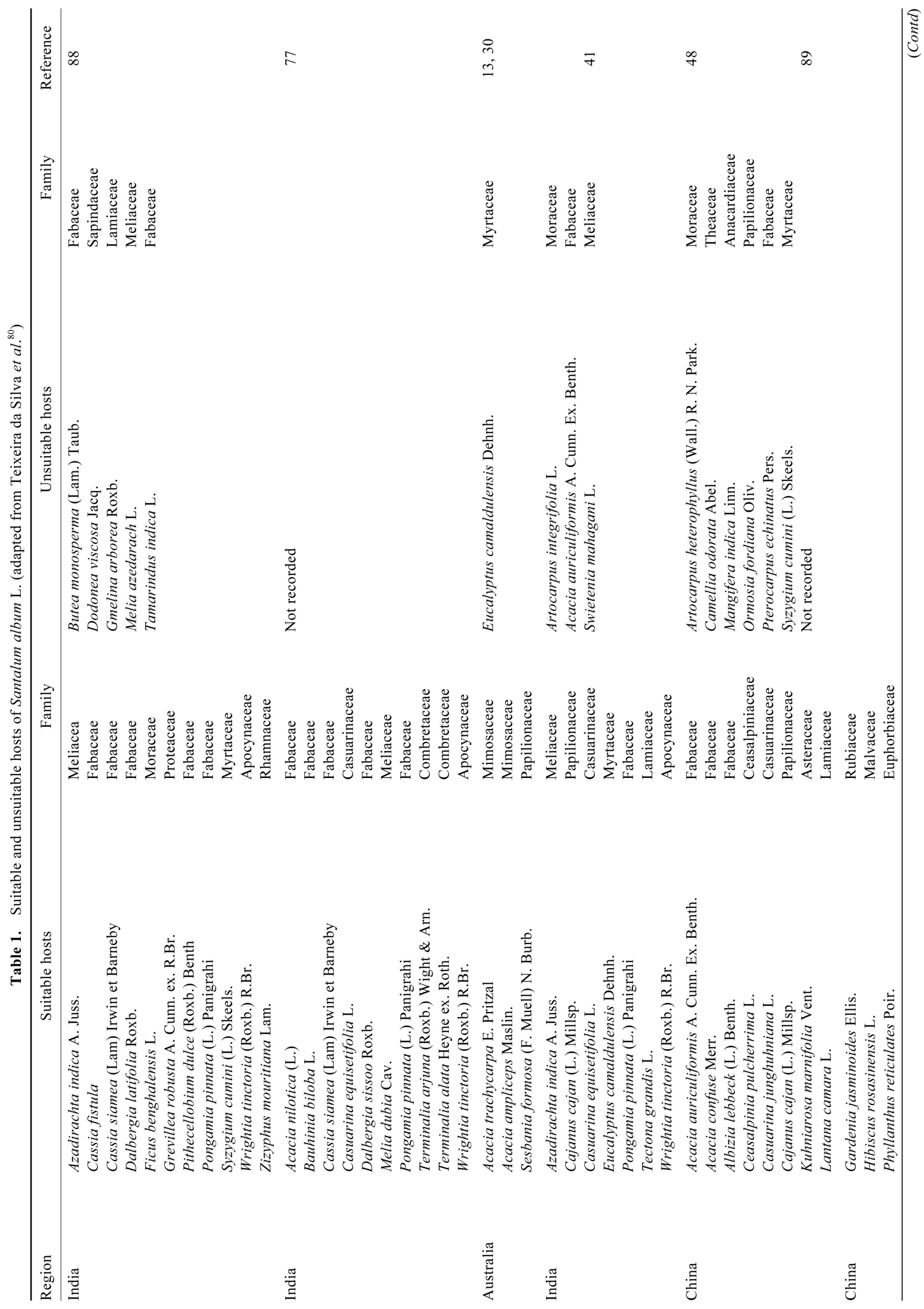

CURRENT SCIENCE, VOL. 120, NO. 7, 10 APRIL 2021 

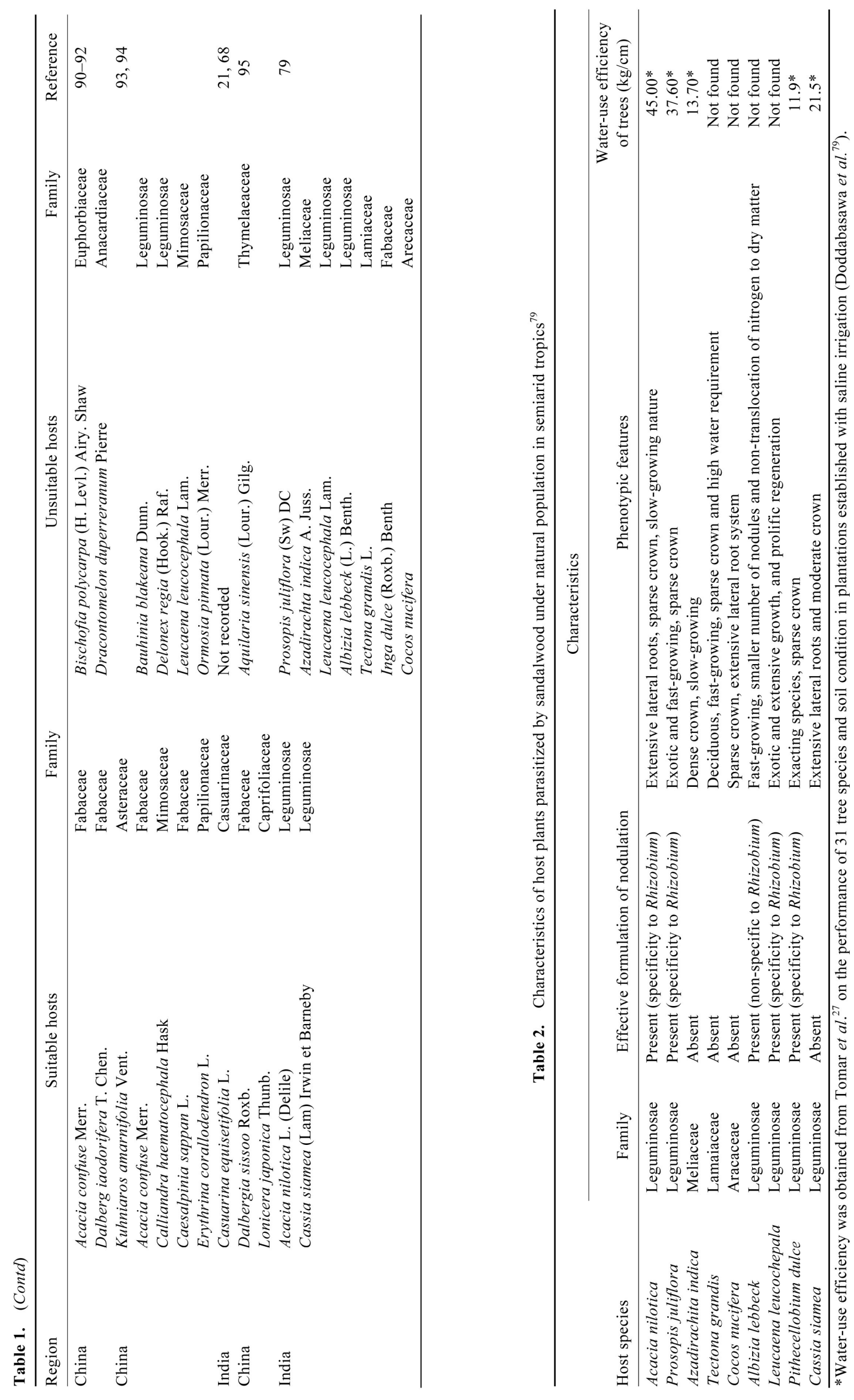
species $^{63,74,75}$. Some studies have documented the decrease in productivity and/or reproductive potential of hosts and even population dynamics of hosts in both root and shoot parasites ${ }^{76}$.

\section{Reverse translocation}

Studies have revealed an increase in mineral and nutrient contents in some host plants due to reverse translocations, especially of $\mathrm{P}, \mathrm{Ca}$ and $\mathrm{Mg}$, which in turn affects the growth and development of sandal ${ }^{77}$. For instance, Rocha et al. $^{21}$ reported $26 \%$ and $35 \%$ reverse translocation of $\mathrm{P}$ from sandal tree to host with Casuarina and teak respectively.

\section{Growth rate of host species}

Sandal is a shade-demander in the early stages and later it needs abundant sunlight for photosynthesis. Therefore, fast-growing host species should not be selected as they are likely to overtop sandal plants. For instance, Barbour $^{78}$ observed suppressed growth of sandal with Khaya senegalensis (African mahogany) due to its rapid growth and large canopy which reduced the availability of sunlight. Similarly, Doddabasawa et al. ${ }^{79}$ reported suppression of sandal growth with the fast-growing and exacting species Leucaena leucocephala and Prosopis juliflora. Slow growing species (Acacia) seem ideal as they have sparse canopy and are thorny in nature. Besides providing shade in the early stages, they also protect sandal plants from browsing animals ${ }^{23}$.

Leguminous plants have an edge over others due to greater availability of nutrients, especially nitrogen and amino acids. Teixerira da Silva et al. ${ }^{80}$ reported association of sandal with Fabaceae, Mimosaceae, Papilionaceae, Casuarinaceae, Meliaceae, Myrtaceae, Apocynaceae, Lamiaceae and Rhamnaceae, the association with Fabaceae being predominant. Further, not all species of these families were good hosts, and even with the leguminous family species such as Tamarindus indica, Butea monosperma, Delonex regia, Bauhinia blakeana and Cassia surattensis were found to be poor hosts (Table 1). Similarly in Australia, Barbour ${ }^{78}$ observed better growth of sandal with leguminous hosts, but not with all leguminous species. In the Indian subcontinent, Doddabasawa et al. ${ }^{79}$ suggested Acacia nilotica and Cassia siamea as the most suitable long-term hosts. The non-suitability of hosts largely depends on the characteristics of host species (Table 2).

\section{Plantation establishment}

\section{Direct sowing of sandalwood seeds}

This method is practised in southwestern Australia, where sandal seeds are sown directly with planted hosts in the field. Acacia acuminatum is planted in the first year followed by sandal in the second and third years. Four untreated seeds of $S$. spicatum are sown around the host as close as practicable at $1 \mathrm{~m}$ distance with a depth of $5 \mathrm{~cm}$ (ref. 81). This technique reduces the cost of cultivation and period of establishment in the field. Secondly, the roots of young sandal seedlings are brittle and so is the haustorial connection formed with the potted hosts, and hence liable for damage even under careful handling during transplantation. However, in the dibbling method survival percentage of sandal as well as host is very low. Alternatively, Woodall and Robinson ${ }^{10}$ found three times (70\%) more successful establishment while sowing pre-germinated sandal seeds with host on the same day compared to the former method.

\section{Seedlings without primary host}

Seedlings raised in containers (sandal relies largely on seed reserves/endosperm in the initial stage for a period of 6 months to 1 year) are planted with host either in the same pit or adjacent to the pit. Planting sandal in the same pit along with host at distance of $20-30 \mathrm{~cm}$ is good. Higher growth rate of host may affect the growth of sandal or vice versa. Initially, it may be good for sandal as it needs shade, but at later stages the host needs to be pruned frequently to enhance the availability of sunlight for sandal. However, frequent pruning may reduce the growth of the host and in turn the accessibility of resources from the host to sandalwood. Further, formation of haustoria on lateral roots of parasites is not only for physiological access but also for physical support. In this context, sandal grown on the same pit may be susceptible to wind. Besides, planting of sandal seedlings without primary host adjacent to the secondary host in the field also results in low success rate and growth of sandal due to poor association with the host and/or it takes longer time for formation of the haustorial attachment with the adjoining hosts. Survival rate and performance of sandal improve when seedlings raised with the primary host in a pot/container are planted adjoining to the secondary host ${ }^{82}$.

\section{Seedlings with primary host}

The sandalwood seedlings initiate haustoria within 30 days after germination with the associated host species ${ }^{35}$. Sandal needs presence of hosts at three different stages; one at seedling stage (primary host/pot host) involves planting of host plants in containers having sandal seedlings during nursery propagation; second at intermediate between nursery and field, and third stage as long-term host in the field throughout the life of the sandal tree (secondary host) $)^{31}$. However, in practice, hosts are being largely used at two stages as primary hosts in seedling 
Table 3. Spacing geometry and host-to-parasite ratio in commercial Santalum album in India

\begin{tabular}{|c|c|c|c|c|}
\hline Spacing adopted & Details & $\begin{array}{l}\text { Host-to-parasite } \\
\quad \text { ratio }\end{array}$ & Population & Reference \\
\hline $5 \mathrm{~m} \times 4 \mathrm{~m}$ & $\begin{array}{l}5 \mathrm{~m} \text { distance between rows and } 4 \mathrm{~m} \text { distance within a row (between } \\
\text { two sandalwood plants one rosewood or teak or eucalyptus was } \\
\text { planted) rendering effective distance between trees within rows in } \\
\text { to } 2 \mathrm{~m}\end{array}$ & $1: 1$ & $\begin{array}{l}500 \text { trees of sandal ha }{ }^{-1} \text { and } \\
500 \text { trees of host }\end{array}$ & 96 \\
\hline $6 \mathrm{~m} \times 3 \mathrm{~m}$ & $\begin{array}{l}\text { With amla at the same spacing between sandal in the quincuncial } \\
\text { method (distance from host is } 3 \mathrm{~m} \text { ) }\end{array}$ & $1: 1$ & $\begin{array}{l}555 \text { trees of sandal ha } \mathrm{ha}^{-1} \text { and } \\
555 \text { tress of amla ha } \\
\text { (total density } 1110 \text { ) }\end{array}$ & 58 \\
\hline $4 \mathrm{~m} \times 4 \mathrm{~m}$ & $\begin{array}{l}\text { With casuarina at the same spacing between sandal in the } \\
\text { quincuncial method (distance from host is } 4 \mathrm{~m} \text { ) }\end{array}$ & $1: 1$ & $\begin{array}{l}555 \text { trees of sandal ha }{ }^{-1} \text { and } \\
555 \text { tress of amla ha } \\
\text { (total density 1110) }\end{array}$ & 58 \\
\hline $4 \mathrm{~m} \times 5 \mathrm{~m}$ & $\begin{array}{l}4 \mathrm{~m} \text { distance between the rows and } 5 \mathrm{~m} \text { distance between plants within } \\
\text { a row; sandalwood was planted at a distance of } 2.5 \mathrm{~m} \text { from the host }\end{array}$ & $1: 1$ & $\begin{array}{l}500 \text { trees of sandal ha }{ }^{-1} \text { and } \\
500 \text { trees of host }\end{array}$ & 70 \\
\hline
\end{tabular}
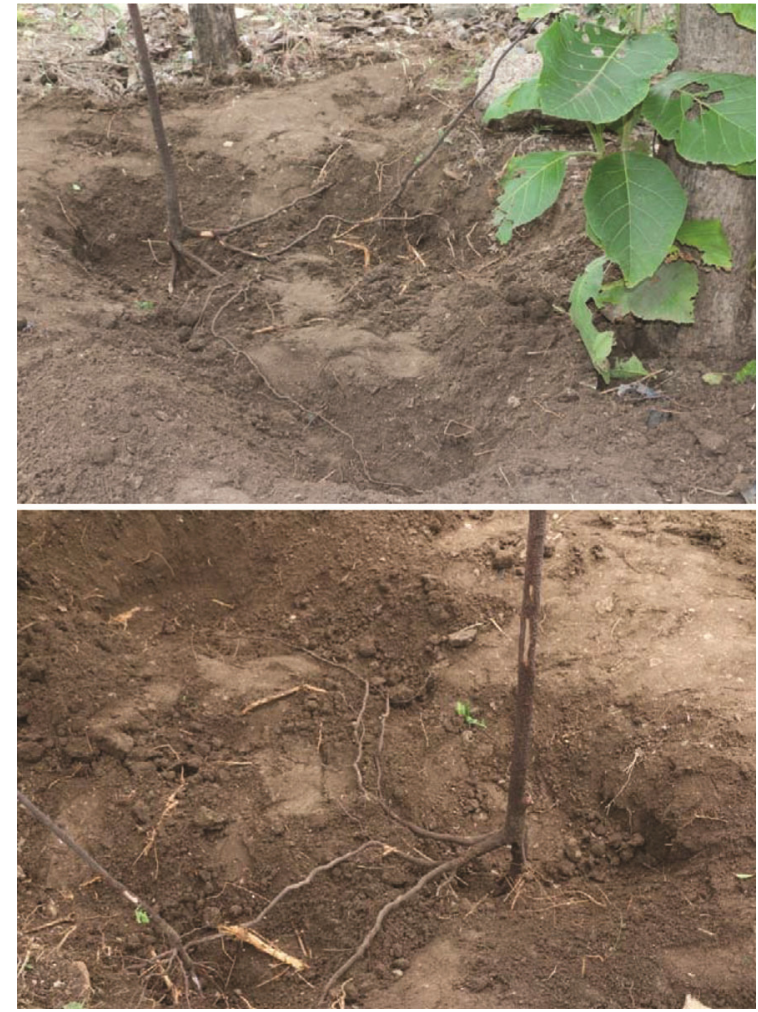

Figure 3. Sandalwood rooting pattern indicating horizontal growth through lateral roots.

stage for a short period of 6 months to 2 years, and secondary hosts in the field as long-term hosts comprising perennial trees. Suitable hosts in the pot and field greatly increase the rate of successful establishment and growth of sandal ${ }^{13,31,37}$.

\section{Spacing and planting density}

Cultivation of sandal is rather complex as it involves both host and parasite, and accommodating them together is rather tricky. Sandalwood can generally extend its lateral roots in the surrounding areas up to $1.5-3 \mathrm{~m}$ for establish- ing association with the host. This extension also helps as a physical anchorage to the sandal plant (Figure 3). Ananthapadmanabha ${ }^{77}$ reported that sandal cannot be grown beyond $2.2 \mathrm{~m}$ from the host plant; otherwise the growth of sandal is significantly hampered. Davit ${ }^{83}$ observed that the attraction of root parasite to the host was limited beyond $3 \mathrm{~m}$. The optimum spacing would be $1.5-3.0 \mathrm{~m}$ (Table 3). In the absence of hosts, sandal was found to parasitize its own root suckers for survival ${ }^{33,84,85}$.

In most instances, the ratio of host to parasite is $1: 1$ (Table 3). This ratio is critical for survival and productivity of sandal trees as well as the host plants. Equal hostto parasite ratio $(1: 1)$ heavily leaning towards parasite leads to heavy parasitic load, and hence may cause death or decline of the host population, decreasing the ratio further. Therefore, host and sandalwood ratio of $2: 1$ and $3: 1$ needs consideration ${ }^{86}$. At present, a spacing of $5 \mathrm{~m} \times 5 \mathrm{~m}$ for the hosts with a sandal plant at the middle of four host plants with host-to-parasite ratio of $4: 1$ is being practised. Further, it is suggested to have hosts of multiple species comprising both leguminous and nonleguminous commercially important trees, with sandal being the subsidiary crop ${ }^{21,87}$.

\section{Conclusion}

Of late the interest in sandal, especially in $S$. album is growing and many commercial plantations are coming up on private lands for its commercial value. Sandal being a hemi-root parasite, interactions between host and sandal are complex and vary with the host and agro-climatic situation. Therefore, we need thorough in-depth knowledge for commercial success. Much of the available information particularly on hosts is from pot-culture studies, and upscaling of these results to the field level is rather difficult to comprehend with regard to economical rotation age, selection of hosts, spacing and host-to-parasite ratio. However, it is suggested to have multiple hosts of commercial importance comprising both perennial leguminous and non-leguminous tree species. Hosts having 
deep root system and slow-growing nature like genus Acacia in $4: 1$ host-to-parasite ratio, with hosts spaced at $5 \mathrm{~m} \times 5 \mathrm{~m}$ and sandal between the four host plants with need-based tending operation.

\section{Future line of work}

Sandal cultivation is a promising venture and with liberalization from governments, commercial production is spreading across the agrarian landscape, however, the production potential is yet unknown and uncertain. Presently, sandal is found to survive with a vast array of plants, especially short-rotation species like Casuarina and in some instances even with fruit trees like citrus, amla, mango and other economical horticultural and forestry species. As a parasite sandal inhibits the associated host, but the economical equilibrium between host and sandalwood is not yet to be ascertained. Perennial trees of long rotational period of 25-30 years would appear beneficial, but there are no long-term studies to confirm this. Being a combination of host and parasite plants, the association is complex and warrants a thorough research back-up with regard to nursery management, early establishment, host-parasite interface, number and type of host/s, their ratio, economic rotation age, watering, fertilization, chemical needs, pest control (if any, in both host and sandalwood), etc. Further, the parasite also has an impact on productivity of the associated economical species. In all, there is a long way to go before appreciation and recommendation of any system for commercial production of sandal.

1. Nageswara Rao, M., Ganeshaiah, K. N. and Uma Shaanker, R., Assessing threats and mapping sandal (Santalum album L.) resources in peninsular India: identification of genetic-hotspot for in situ conservation. Conserv. Genet., 2007, 8, 925-935.

2. Meera, C., Nageswara Rao, M., Ganeshaiah, K. N., Uma Shaanker, R. and Swaminath, M. H., Conservation of sandal genetic resources in India: I Extraction patterns and threats to sandal resources in Karnataka. My For., 2000, 36,125-132.

3. Sreenivasan, V. V., Shivaramakrishnana, V. R., Rangaswamy, C. R., Anathapadmanabha, H. S. and Shankaranarayana, K. H., Sandal, ICFRE, Dehra Dun, 1992, p. 233.

4. Suma, T. B. and Balasundaran, M., Isozyme variation in five provenances of Santalum album in India. A. J. Bot., 2003, 51, 243-249.

5. Gairola, S., Aggarwal, P. S. and Ravikumar, G. S., Status of production and marketing of sandalwood (Santalum album L.). In Proceedings of the National Seminar on Conservation, Improvement, Cultivation and Management of Sandal (eds Gairola, S. et al.), 12-13 December 2007, pp. 1-8.

6. Gillieson, D., Page, T. and Silverman, J., An Inventory of Wild Sandalwood Stocks in Vanuatu, Australian Centre for International Agricultural Research, Canberra. 2008, p. 118.

7. Subasinghe, S. M. C. U. P., Sandalwood research: a global perspective. J. Trop. For. Environ., 2013, 3, 1-8.

8. Baldovini, N., Delasalle, C. and Joulain, D., Phytochemistry of the heartwood from fragrant santalum species: a review. Flavour Frag. J., 2011, 26, 7-26.
9. Surendran, C., Parthiban, K. L., Bhuvaneswaran, C. and Murgesh, M., Silvicultural strategies for augmentation of sandal regeneration (1998). In ACIAR Proceedings of the Conference on Sandal, Bangalore, 18-19 December 1997, pp. 69-73.

10. Woodall, G. S. and Robinson, C. J., Same day plantation establishment of the root hemiparasite sandalwood Santalum spicatum (R.Br.) A D. C: Santalaceae and its hosts. J. R. Soc., W. Aust., 2002, 85, 37-42.

11. Arun Kumar, A. N., Geeta, J. and Mohan Ram, H. Y., Sandalwood: history, uses and present status and the future. Curr. Sci., 2012, 103(12), 1408-1416.

12. Nageswara Rao, M., Soneji, J. R. and Sudarshana, P., Santalum. In Wild Crop Relatives: Genomic and Breeding Resources (ed. Kole, C.), Springer, Berlin, Germany, 2011, pp. 131-144; doi:10.1007/ 978-3-642-21250-5.

13. Radomiljac, A. M., Anathapadmanabha, H. S., Welbourn, R. M. and Satyanarayana Rao, K., The effect of sandalwood availability on the craftsman community. In Sandal and its Products. ACIAR Proceedings (84), Australian Centre for International Agricultural Research, Canberra, Australia, 1998, p. 204.

14. Heena Kausar, S., Jahan, N., Ahmed, K., Aslam, M., Ahmed, P. and Ahmed, S., Unani perspective and recent studies of sandal safed (Santalum album Linn.): a review. World J Pharm. Sci., 2014, 3, 2133-2145.

15. Sen Sarma, P. K., Sandalwood - its cultivation and utilization. In Cultivation and Utilization of Aromatic Plants (eds Atal, C. K. and Kapur, B. M.), Regional Research Laboratory, CSIR, Jammu Tawi, 1982, pp. 395-495.

16. Troup, R. S., The Silviculture of Indian Trees, Clarendon Press, Oxford, UK, 1921, vol. 3, p. 817.

17. Neil, P. E., Growing sandalwood in Nepal: potential silvicultural methods and research priorities. USDA Forest Service General Technical Report, 1990, p. 122.

18. Barber, C. A., Studies in root parasitism-the houstorium of Santalum album L. 1. Early stages up to penetration. Mem. Dept. Agric. Ind. Bot. Ser. 1, 1903, 1, 1-26.

19. Barber, C. A., Studies in root parasitism: the haustoria of Santalum album L. Mem Dept. Agric. India Bot. Ser. 1 Part 1, 1906, 1, $1-26$.

20. Taide, Y. B., Babu, L. C. and Abraham, C. C., Influence of host species on the initial growth and development of sandal ( $S$. album L.). Indian J. For., 1994, 174, 288-292.

21. Rocha, D., Ashokan, P. K., Santhoshkumar, A. V., Anoop, E. V. and Sureshkumar, P., Anatomy and functional status of haustoria in field-grown sandalwood tree (Santalum album L.). For. Res., 2015, 148; doi:10.4172/2168-9776.1000148.

22. Kuijt, J., The Biology of Parasitic Flowering Plants, University of California Press, Berkeley, CA, USA, 1969.

23. Barrett, D. and Fox, J. E. D., Early growth of santalum album relation to shade. Aust. J. Bot., 1994, 42, 83-93.

24. Barrett, D. and Fox, J. E. D., A protocol suitable for raising seedlings of S. album in Timor. In Sandalwood Seed Nursery and Plantation Technology (eds Gyerum, L., Fox, J. E. D. and Ehrhart, L.), Field Document. FAO, Suva, Fiji, 1995, pp. 163-164.

25. Sreenivasan Rao, Y. V., Contributions to the physiology of sandal (Santalum album L.). Influence of the host plants on the nitrogen metabolism of sandal. J. Indian Inst. Sci., 1933, 16, 164-184.

26. Iyengar, A. V. V., The relation of soil nutrients to the incidence of spike disease in sandalwood (Santalum album Linn.). Indian For., 1960, 86, 220-230.

27. Rangaswamy, C. R., Jain, S. H. and Parthasarthi, K., Soil properties of some sandalwood bearing areas. Van Vigyan, 1986, 24, 61-68.

28. Parthasarathi, K. and Rao, P. S., Studies on sandal spike: physiological significance of disturbed iron balance in the spike disease of sandal (S. album L.). Proc. Indian Acad. Sci., Sect. B, 1962, 55, 99-106. 
29. Srimathi, R. A., Babu, D. R. C. and Sreenivasaya, M., Influence of host plant on the amino acid make up of Santalum album. Curr. Sci., 1961, 30(11), 417.

30. Radomiljac, A. M., McComb, J. A. and McGrath, J. F., Intermediate host influences on the root hemi-parasite Santalum album L. biomass partitioning. For. Ecol. Manage., 1999, 113, 143-153.

31. Ehrhart, Y. and Fox, J. E. D., State of knowledge regarding cultivation of sandalwood. In Sandalwood Seed Nursery and Plantation Technology (eds Gjerum L., Fox, J. E. D. and Ehrhart, Y.), Proceedings of a Regional Workshop for Pacific Island Countries, Noume'a, New Caledonia, FAO, Suva, Fiji, 1-11 August 1994, pp. 275-291.

32. Fox, J. E. D., Doronila, A. I., Barrett, D. R. and Surata, I. K., Desmanthus virgatus (L.) Willd. An efficient intermediate host for the parasitic species Santalum album L. in Timor, Indonesia. J. Sustain For., 1996, 3, 13-23; doi:10.1300/J091v03n04_02.

33. Rao, M. R., Host plants of the sandal tree. Indian For., 1911, 2, 159-207.

34. Nagaveni, H. C. and Srimathi, R. A., Studies on germination of sandal (Santalum album L.) pre-treatment of sandal seeds. Indian For., 1981, 107, 348-354.

35. Nagaveni, H. C. and Srimathi, R. A., A note on haustoria-less sandal plants. Indian For., 1985, 111, 615-618.

36. Barrett, D. and Fox, J. E. D., Santalum album: kernel composition, morphological and nutrient characteristics of pre-parasitic seedlings under various nutrient regimes. Ann. Bot., 1997, 79, 59-66; doi:10.1006/anbo.1996.0303.

37. Surata, K., Effect of host plants on growth of sandalwood (Santalum album) seedlings. Santalum, 1992, 9, 1-10.

38. Shinde, S., Ghatge, R. and Mehetre, S., Comparative studies on the growth and development of sandalwood tree in association with different hosts. Indian J. For., 1993, 16, 165-166.

39. Fox, J. E. D., Doronila, A. I. and Barrett, D. R., The selection of superior pot hosts for maximum nursery growth in Santalum album. Papers presented at the Sandalwood workshop held at Noumea, New Caledonia, Australian Centre for International Agricultural Research, CIRAD/FAO, 12 August 1994, p. 111.

40. Rai, S. N., Status and cultivation of sandalwood in India. In Proceedings of the Symposium on Sandalwood in the Pacific (eds Hamilton L. and Conrad, C. E.), USDA Forest Service General Technical Report, PSW-122, USA, 1990, pp. 66-71.

41. Nagaveni, H. C. and Vijayalakshmi, G., Growth performance of sandal (Santalum album L.) with different host species. Sandalwood Res. Newsl., 2003, 18, 1-4.

42. Venkata Rao, M. G., The influence of host plants on sandal spike disease. Indian For., 1938, 64, 656-669.

43. Ananthapadmanabha, H. S., Nagaveni, H. C. and Rai, S. N., Influence of host plants on the growth of sandal. My For., 1988, 24, $154-160$.

44. Nagaveni, H. C. and Vijiyalakshmi, G., Growth performance of sandal (Santalum album L.) with different leguminous and nonleguminous host species. Sandalwood Res. Newsl., 2004, 18, 1-4.

45. Nagaveni, H. C. and Vijayalakshmi, G., Differential response in the haustorial formation and growth of sandalwood plants (Santalum album Linn.) with respect different hosts. In National Seminar on Conservation, Improvement, Cultivation and Management of Sandal, IWST Bengaluru, 12-13 December 2007, pp. 137-142.

46. Irawan, T., A study report on the effect of host diversity on growth and development of sandalwood in Kupang. In Thomas Lion (2017), Sandalwood cultivation. Int. J. Dev. Res., 2017, 7(8), 14826-14830.

47. Deepa, P. and Yusuf, A., Influence of different host associations on glutamine synthetase activities and ammonium transporter in Santalum album L. Physiol. Mol. Biol. Plants, 2016, 22(3), 331340 .

48. Li, Y. L., Sandalwood Introduction and Research (in Chinese), Science Press, Beijing, China, 2003, p. 3.
49. Matthies, D., Parasite-host interaction in Castillega and Orthocarpus. Can. J. Bot., 1997, 751, 1252-1260.

50. Barrett, D. J., Hatton, T. J., Ash, J. E. and Ball, M. C., Transpiration by trees from contrasting forest types. Aust. J. Bot., 1996, 44, 249-263.

51. Brand, J. E., Crombie, D. S. and Mitchell, M. D., Establishment and growth of sandalwood (Santalum spicatum) in south-western Australia: the influence of host species. Aust. For., 2000, 63, 6065; doi:10.1080/00049158.2000.10674814.

52. Brand, J. E., Ryan, P. C. and Williams, M. R., Establishment and growth of sandalwood (Santalum spicatum) in south-western Australia: the Northampton pilot trial. Aust. For., 1999, 62, 33-37.

53. Barrett, D. R., Wijesuriya, S. R. and Fox, J. E. D., Observations on foliar nutrient content of sandalwood (Santalum spicatum R.Br. D.C.). Mulga Res. Centre J., 1985, 8, 81-91.

54. Barrett, D. R., Santalum album (Indian sandalwood) literature survey. Mulga Res. Centre, Curtin University, Perth, Australia, 1988, p. 5.

55. Sen-Sarma, P. K., Some aspects of ecology of sandal spike disease. In Proceedings of All India Sandal Seminar, Karnataka Forest Department, Bangalore, 1977, pp. 163-166.

56. Sreenivasan, V. V., Shivaramakrishnana, V. R., Rangaswamy, C. R., Anathapadmanabha, H. S. and Shankaranarayana, K. H., Sandal, ICFRE, Dehra Dun, 1992, p. 233.

57. McKinell, F. H., Status of management and silviculture research on sandalwood in Western Australia and Indonesia. In Proceedings of the Symposium on Sandalwood in the Pacific (eds Hamilton, L. and Conrad, C. E.), United States Department of Agriculture, General Technical Report, PSW-122, Hawaii, 1990, pp. 19-25.

58. Viswanath, S., Dhanya, B., Purushothaman, S. and Rathore, T. S., Financial viability of sandal (Santalum album) based agroforestry practices in Southern India. Indian J. Agrofor., 2010, 12(2), 1422.

59. Jonathan, E. B., Len, J. N. and Ian, C. D., Estimated heartwood wiehgts and oil concentrations within 16 year old Indian sandalwood (Santalum album) trees planted near Kununurra, Wesstern Australia. Aust. For., 2012, 75(4), 225-232.

60. Kelly, C. K., Venable, D. L. and Zimmerer, K., Host specialization in Cuscuta costaricensis: an assessment of host use relative to host availability. Oikos, 1988, 53, 315-320.

61. Tennakoon, K. U., Ekanayake, S. P. and Etampawala, L., An introduction and current status of sandalwood research in Sri Lanka. Int. Sandalwood Res. Newsl., 2000, 10, 1-4.

62. Wawo, A. H., Cendana, Deregulation and Strategy, Pengembangannya, Bogor (2002). In Thomas Lion (2017) Sandalwood cultivation. Int. J. Dev. Res., 2017, 7(8), 14826-14830.

63. Cameron, D. D., Hwangbo, J. K., Keith, A., Geniez, J. M., Kraushaar, D., Rowntree, J. and Seel, W. E., Interactions between the hemiparasitic angiosperm Rhinanthus minor and its hosts: from the cell to the ecosystem. Folia Geobot., 2005, 40, 217229.

64. Varghese, S., Parasitic interference of sandal (Santalum album Linn.) on common agricultural crops from the homesteads. M.Sc. thesis, Kerala Agricultural University, Thrissur, 1997.

65. Vijayakumar, H., Hiremath, J. and Ashokan, P. K., Influence of soil moisture regimes and stage of host introduction on seedling growth of sandal provenances. In National Seminar on Conservation, Improvement, Cultivation and Management of Sandal, IWST Bengaluru, 12-13 December 2007, pp. 59-66.

66. Dhaniklal, G., Influence of host plants on soil moisture stress on the water relations in sandal. M.Sc. thesis, Kerala Agricultural University, Thrissur, 2006.

67. Ashokan, P. K. and Krishnambika, N., Growing sandal in home garden and other agroforestry systems - potentials and problems. In Proceedings of a National Seminar, IWST, Bangalore, 12-13 December 2007, pp. 143-152. 
68. Rocha, D., Ashokan, P. K., Santhoshkumar, A. V., Anoop, E. V. and Sureshkumar, P., Influence of host plant on the physiological attributes of field-grown sandal tree (Santalum album). J. Trop. For. Sci., 2014, 26, 166-172.

69. Pate, J. S., Kuo, J. and Davidson, N. J., Growth, resource allocation and haustorial biology of the root hemiparasite Olax phyllanthi (Olacaceae), with special reference to the haustorial interface. Ann. Bot., 1990, 65, 425-436.

70. Babita, M., Sandeep, C., Sandhya, M. C. and Viswanath, S., Sandalwood farming in India: problems and prospectus. Indian J. Trop. Biodivers., 2018, 26(1), 1-12.

71. Ananthapadmanabha, H. S., Indian sandalwood market trend and production. In International Seminar on Sandalwood: Current Trends and Future Prospects (ed. Ramakantha, V.), Institute of Wood Science and Technology, Indian Council of Forestry Research and Education, Bangalore, 2014, p. 74.

72. Viswanath, S., Ahmed, S. M., Madhu, K. S., Kumar, N. P., Sowmya, C., Arade, S. C. and Adhikari, M., Performance of sandalwood based agroforestry models with horticulture crops as secondary hosts in Karnataka. Abstracts of International Seminar on Sandalwood: Current Trends and Future Prospects, IWST, Bangalore, 26-28 February 2014, p. 24.

73. Singh, B., Rathore, T. S. and Singh, G., The effect of long term hosts species on Santalum album L. growth under agroforestry in semi-arid condition of North Gujarat, India. In Abstracts of International Seminar on Sandalwood: Current Trends and Future Prospects, IWST, Bangalore, 26-28 February 2014, p. 26.

74. Hibberd, J. M., Quick, W. P., Press, M. C. and Scholes, J. D., The influence of the parasitic angiosperm Striga gesnerioides on the growth and photosynthesis of its host, Vigna unguiculata. J. Exp. Bot., 1996, 47, 507-512.

75. Fisher, J. P., Phoenix, G. K., Childs, D. Z., Press, M. C., Smith, S. W., Pilkington, M. G. and Cameron, D. D., Parasitic plant litter input: a novel indirect mechanism influencing plant community structure. New Phytol., 2013, 198, 222-231.

76. Press, M. C., Scholes, J. D. and Watling, J. R., Parasitic plants: physiological and ecological interactions with their hosts. In Physiological Plant Ecology (eds Press, M. C., Scholes, J. D. and Barker, M. G.), Blackwell, Science, Oxford, UK, 1999, pp. 175197.

77. Ananthapadmanabha, H. S., Rangaswamy, C. R., Sarma, C. R., Nagaveni, H. C., Jain, S. H., Venkatesan, K. R. and Krishnappa, H. P., Host requirement of sandal (Santalum album L.). Indian For., 1984, 110(3), 264-268.

78. Barbour, L., Analysis of plant-host relationships in tropical sandalwood (Santalum album). Rural Indust. Res. Develop. Corp., Kununurra, Western Australia, 2008, 8(138), pp. 1-25.

79. Doddabasawa, Chittapur, B. M. and Lokesh, R., Parasitism ecology of sandalwood (Santalum album L.) for commercial production in the semi-arid tropics. Curr. Sci., 2020, 119(4), 699703 .

80. Teixeira da Silva, J. A., Kher, M. M., Soner, D., Page, T., Zhang, X., Nataraj, M. and Ma, G., Sandalwood: basic biology, tissue culture and genetic transformation. Planta, 2016, 243, 847-887.

81. Brand, J. E. and Jones, P., Growing sandalwood (Santalum spicatum) on farmland in Western Australia. Forest Products Commission, Western Australia, Perth, Australia, 2001, pp. 1-25.

82. Annapurna, D., Rathore, T. S. and Joshi, G., Modern nursery practices in the production of quality seedlings of Indian sandalwood (Santalum album L.) - stage of host requirement and screening of primary host species. J. Sustain For., 2006, 22, 33-55; doi:10.1300/J091v22n03_03.
83. Davit, M. W., Determinants of parasitic plant distribution: the role of host quality. Botany, 2009, 87(1), 16-21.

84. Rai, S. N. and Sarma, C. R., Study of diameter growth in sandal. J. Trop. For., 1986, 2, 202-206.

85. Iyenger, A. V. V., The physiology of root parasitism in sandal (Santalum album L.). Indian For., 1965, 91, 246-256.

86. McComb, J. A., Clonal Santalum album growth, oil content and composition on different hosts and at different locations. J. Roy. Soc. W. Aust., 2009, 92, 15-25.

87. Rocha, D., Ashokan, P. K., Santhoshkumar, A. V., Anoop, E. V. and Sureshkumar, P., Anatomy and functional status of haustoria in field grown sandalwood tree (Santalum album L.). Curr. Sci., 2017, 113(1), 130-133.

88. Parthasarathi, K., Gupta, S. K. and Rao, P. S., Differential response in the cation exchange capacity of the host plants on parasitization on sandal (Santalum album). Curr. Sci., 1974, 43, 17-20.

89. Ma, G. H., He, Y. M., Zhang, J. F. and Chen, F. L., Studies on semi-parasitic sandalwood seedlings. J. Trop. Subtrop. Bot., 2005, 13, 233-238.

90. Lu, J. K., The parasitism between hemiparasite Santalum album and its hosts. Ph.D. thesis, Chinese Academy of Forestry, Beijing, China, 2011, p. 37.

91. Lu, J. K., Kang, L. H., Sprent, J. I., Xu, D. P. and He, X. H., Two way transfer of nitrogen between Dalbergia odorifera and its hemiparasite Santalum album is enhanced when the host is effectively nodulated and fixing nitrogen. Tree Physiol., 2013, 33, 464474.

92. Lu, J., Xu, D., Kang, L. and He, X., Host-species-dependent physiological characteristics of hemiparasite Santalum album in association with $\mathrm{N}_{2}$-fixing and non- $\mathrm{N}_{2}$-fixing hosts native to southern China. Tree Physiol., 2014, 34, 1006-1017.

93. Zhang, X. H., Teixeira da Silva, J. A., Duan, J., Deng, R., Xu, X. and $\mathrm{Ma}, \mathrm{G} . \mathrm{H}$., Endogenous hormone levels and anatomical characters of haustoria in Santalum album L. seedlings before and after attachment to the host. J. Plant Physiol., 2012, 169, 859866; doi:10.1016/j.jplph.2012.02.010.

94. Chen, R., Zhang, X. H. and Ma, G. H., Studies on parasitic relationship between Santalum album L and leguminous plants. J. Trop. Subtrop. Bot., 2014, 22, 53-60.

95. Ouyang, Y., Zhang, X. H., Chen, Y. L., Teixeira da Silva, J. A. and Ma, G. H., Growth, photosynthesis and haustorial development of semiparasitic Santalum album L. penetrating into roots of three hosts: a comparative study. Trees-Struct. Funct., 2015, 1-13; doi:10.1007/s00468-015-1303-3.

96. Reddy, G. R. S., Honnuri, M. B. and Lokeshwara Rao, M., Evaluation of performance of sandal (Santalum album L.) germplasm under agroforestry conditions at Hyderabad. In National Seminar on Conservation, Improvement, Cultivation and Management of Sandal (Santalum album L.), IWAST, Bengaluru, 12-13 December 2007, pp. 107-105.

ACKNOWLEDGEMENT. We thank Dr M. Shankarmurthy, Assistant Professor of Agricultural Entomology, College of Agriculture, Bheemarayanagudi, for the photographs.

Received 25 August 2020; revised accepted 7 December 2020

doi: $10.18520 / \mathrm{cs} / \mathrm{v} 120 / \mathrm{i} 7 / 1184-1193$ 